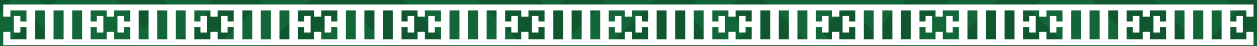

U.S. DOE OFFICE OF INDIAN ENERGY

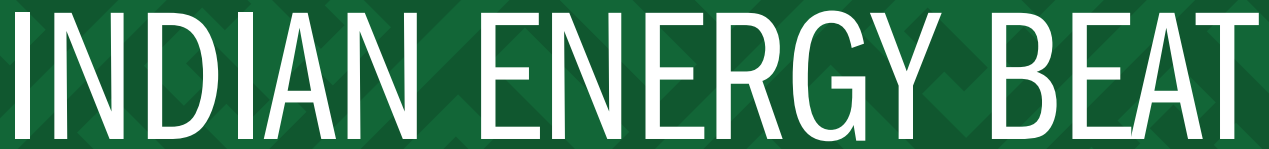

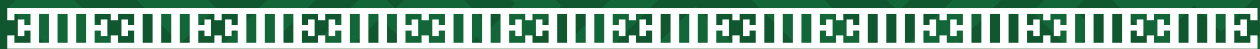

News on Actions to Accelerate Energy Development in Indian Country
INSIDE THIS ISSUE:

BUILDING BRIDGES

MESSAGE FROM THE DIRECTOR

SHARING KNOWLEDGE

OPENING DOORS

WINNING THE FUTURE.

LEADING THE CHARGE

ON THE HORIZON

\title{
Educational Curriculum Supports Tribal Energy Development Efforts
}

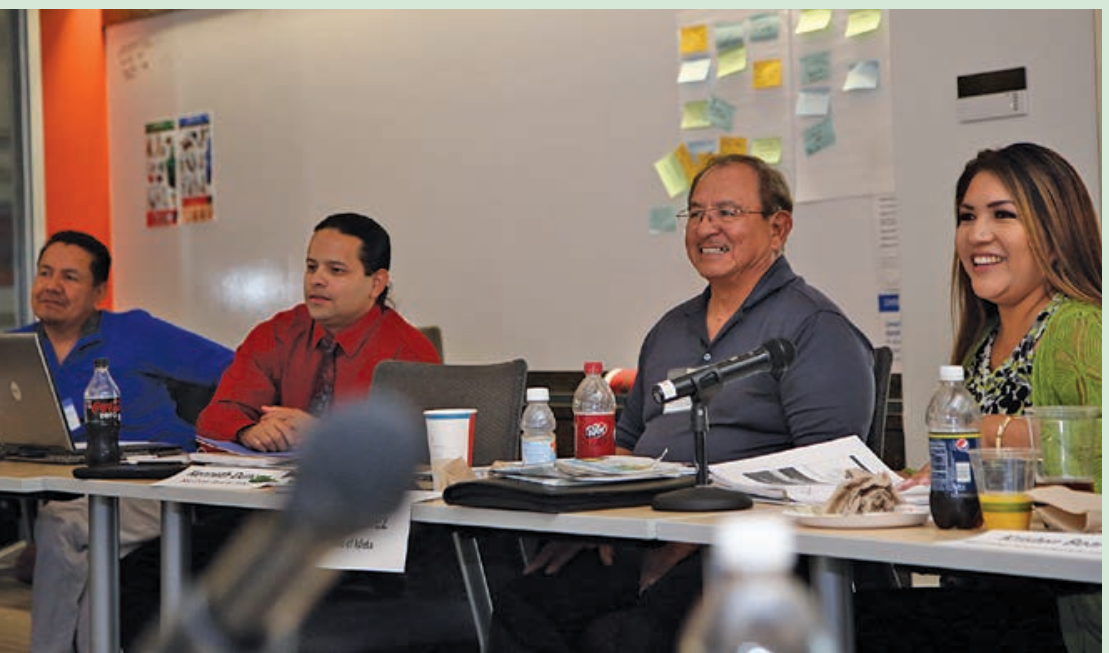

Vernon Masayesva of Black Mesa Trust, Gerald Warrington of the Menominee Tribe of Wisconsin, Vince Gomez of the Pueblo of Isleta, and Lori Bear of Skull Valley Band of Geschute Indians playing a game of Jeopardy during the Commercial-Scale Renewable Energy Project Development and Finance Workshop held in July. Photo by John De La Rosa, NREL 26517

\section{UPCOMING WORKSHOPS}

Community- and Facility-Scale Tribal Renewable Energy Project Development and Finance Workshop

\section{September 18-20, 2013, Denver, Colorado}

Will walk tribal leaders and staff through five steps to help them understand the process for and potential pitfalls of developing community- and facility-scale renewable energy projects.

\section{Alaska Native Village Energy Development Workshop}

October 21-23, 2013, Fairbanks, Alaska

Designed to help Alaska Native villages and corporations understand the range of energy efficiency and renewable energy opportunities that exist in their remote communities.

Learn more and register for these workshops at www.energy.gov/indianenergy. Access the curricula online at www.nterlearning.org (search for "Indian Energy").
Renewable energy projects offer many potential benefits to Tribes, from more stable energy costs and enhanced energy security to higher-quality jobs and a stronger economy. To realize these benefits, many tribal communities are engaging in strategic project planning to develop knowledge and tools that provide them with a better shot at project success.

The U.S. Department of Energy (DOE) Office of Indian Energy and the National Renewable Energy Laboratory (NREL) have developed a series of online educational courses on strategic energy planning, assessing renewable energy resources, renewable energy technology basics, and project development and financing-all to help Tribes identify best practices for pursuing energy projects.

In addition to the online curriculum, tribal leaders and staff have the opportunity to attend in-person workshops, the first of which took place July 9-11 at NREL in Denver, Colorado. Built around a pilot workshop held at NREL last June, the highly interactive workshop was designed to guide participants through the process and potential pitfalls of developing commercial-scale renewable energy projects in Indian Country.

Twenty people from 13 Tribes participated in the training, which included not only listening to presentations but also working though exercises with NREL technical experts to gain hands-on experience with identifying project potential, reviewing maps to make site selections, writing and evaluating requests for proposals, and determining which business structures and finance options best served the project goals of the Tribe.

Attendees also heard from guest speakers Bill Cornelius (Oneida Seven Generations Corporation), Rebecca Kauffman (Southern Ute Tribe), and Jennifer Carleton (Moapa Band of Paiutes), who shared their first-hand experience, insights, and lessons learned from developing renewable energy projects.

After the workshop, Gerald Warrington, project manager for the Menominee Tribe of Wisconsin said, "I have a deeper understanding of renewable commercial projects and financing. I also understand what is practical and what is not. This training will definitely help the Tribe formulate a solid strategic comprehensive energy plan." 


\section{IIBUILDING BRIDGES}

SEVEN NEW INDIAN COUNTRY ENERGY AND INFRASTRUCTURE WORKING GROUP MEMBERS ANNOUNCED

In April, the Indian Country Energy and Infrastructure Working Group (ICEIWG) announced seven new members who will help the Working Group continue to foster collaborative dialogue between DOE and tribal nations on obstacles and opportunities in energy and related infrastructure development, as well as capacity building in Indian Country.

- Blue Lake Rancheria: Jana Ganion, Blue Lake Rancheria Energy Director

- Mississippi Band of Choctaw Indians: Harrison Ben, Tribal Council Representative

- Passamaquoddy Tribe at Indian Township: Joseph Socobasin, Tribal Chief

- Seminole Tribe of Florida: James E. Billie, Chairman

- Sisseton Wahpeton Oyate Tribe: Robert Shepherd, Chairman

- Three Affiliated Tribes: Tex Hall, Chairman

- Yurok Tribe: Susan Masten, Vice Chairperson.

These new members join the following existing Working Group members:

- Confederated Tribes of the Warm Springs Reservation of Oregon: Jim Manion, Warm Springs Power General Manager

- Ewiiaapaayp Band of Kumeyaay Indians: William Micklin, Chief Executive Officer

- Gila River Indian Community: Barney Enos, Jr., District 4 Community Council

- Ho-Chunk Nation: Susan Weber, Representative.

"The Working Group is honored to welcome these new members and would like to thank our current and previous members for their time and commitment," said DOE Office of Indian Energy Director Tracey LeBeau. View ICEIWG meeting agendas and summaries at www.energy.gov/indianenergy/services-0/ indian-country-energyandinfrastructure-working-group.

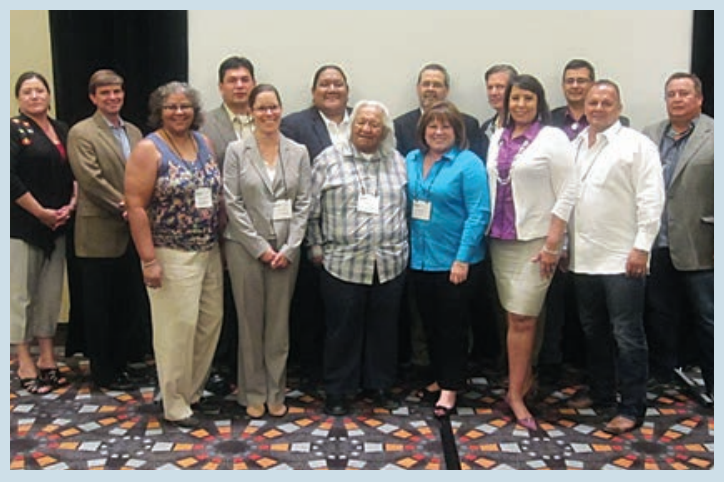

ICEIWG membership nearly doubled in April. Photo from Brooke Oleen, National Conference of State Legislatures

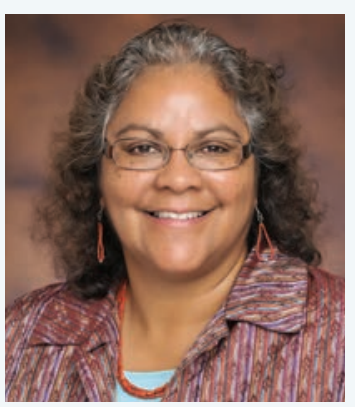

MESSAGE FROM THE DIRECTOR
PILAR THOMAS

Dear Friends,

As the Acting Director of the DOE Office of Indian Energy while Tracey LeBeau is on detail with the Western Area Power Administration (WAPA), I am pleased to announce we have made the final selections for the 2013 Strategic Technical Assistance

Response Team (START) Program. We had great interest in this opportunity, which builds on the achievements and lessons learned from the first round of START and will help even more tribal communities across the country deploy sustainable energy resources and increase local generation capacity. See the lead story in Opening Doors (page 3) for more information.

In addition to the on-the-ground technical assistance we are providing through START, in May we announced up to $\$ 7$ million in funding for tribal energy resource development organizations and tribal consortia to install community- or facility-scale clean energy projects.

Our Office has also been very busy working to build tribal energy capacity by leading panel discussions at events such as Reservation Economic Summit 2013 and the Alaska Rural Energy Conference, offering webinars on transmission and military topics, and publishing analyses on tribal renewable energy project financing in Alaska and potential opportunities for Tribes to sell renewable energy to U.S. military installations.

This fall we will host two workshops

to further educate Tribes on

developing and financing renewable

energy projects, and complete

an electrification study to provide

updated information to help advance development of tribal communityscale energy systems and utilities.

We continue to engage tribal leaders regarding energy-related obstacles and opportunities through the Indian Country Energy and Infrastructure Working Group, which welcomed seven new appointees in April.

I encourage you to keep up on our latest news and activities by subscribing to our email list at www.indianenergy@hq.doe.gov and visiting our website at www.energy.gov/indianenergy.

_Pilar Thomas

\section{SHARING KNOWLEDGE Military Installations Offer Economic Development Opportunity for Tribes}

- There are $\mathbf{5 3}$ reservations located within $\mathbf{1 0}$ miles of military bases.

- The top 15 reservations with tribal installation energy potential have been identified.

- Partnering with military installations may help Tribes gain additional income from land leases, energy sales, and workforce development.

Learn more about the opportunities for Tribes to work with military installations in the DOE Office of Indian Energy's Military Base Off-Taker Opportunities for Tribal Renewable Energy Projects report, which can be downloaded at www.nrel.gov/docs/fy13osti/57501.pdf, and Defense Department Contracting Requirements for Energy Procurement webinar at www.youtube. com/watch?v=uNfvkD5-QW4\&feature=youtu.be. Access presentations from the Tribal Leader Energy Forum held May 30-31 in Chandler, Arizona, on Leveraging Tribal Renewable Resources to Support Military Energy Goals, at www.energy.gov/indianenergy/downloads/ leveraging-tribal-renewable-resources-support-military-energy-goals. 


\section{Tribes Selected for 2013 START Program}

The DOE Office of Indian Energy recently announced 10 projects for its 2013 START Program. These awards represent a significant expansion of the technical assistance the Office provided in support of 11 tribal clean energy projects in 2012.

Through the START Program, DOE works directly with Tribes to evaluate project financial and technical feasibility, provide ongoing training to community members, and help implement a variety of clean energy projects.

\section{START Alaska Community Energy Planning} The DOE Office of Indian Energy, in partnership with the Denali Commission, will assist the following Alaska projects:

- Native Village of Kongiganak-improvements to existing wind energy infrastructure, efficiency measures, and smart grid technology development

- Native Village of Koyukuk-energy infrastructure upgrades and identification of energy efficiency and biomass opportunities
- Native Village of Minto-identification of energy efficiency, biomass, and solar energy opportunities

- Native Village of Shishmaref-local capacity building aimed at mitigating current energy and community relocation challenges, and increasing sustainability

- Yakutat T'lingit Tribe-prioritization of renewable energy projects, evaluation of feasibility studies, community outreach, and identification of steps to move projects forward, including biomass, ocean energy, and efficiency measures.

\section{START Renewable Energy Project} Development Technical Assistance DOE will also assist with project development efforts aimed at advancing the following tribal renewable energy projects:

\section{- Chugachmiut Regional Corporation in Port} Graham, Alaska - an energy-efficient biomass plant that will use local wood to generate power for community buildings in the Native Village of Port Graham

\section{- Ho-Chunk Nation in Black River Falls,} Wisconsin-a 1- to 2-megawatt (MW) biomass waste-to-energy plant that could potentially use municipal solid waste, agriculture waste, or other biomass resources to offset tribal facility energy costs

- Pinoleville Pomo Nation in Ukiah, Californiaa 3-MW solar utility project that will generate an estimated 5,000 megawatt-hours of electricity to power the Tribe's administration buildings and a 24-acre tribal subdivision

- San Carlos Apache Tribe in San Carlos, Arizona-a 1-MW solar photovoltaic (PV) array to be installed on tribal land leased to the tribal casino

- Southern Ute Indian Tribe in Ignacio, Colorado - a solar PV project that will power tribal facilities and residences.

Get more information on the START Program at www. energy.gov/indianenergy/resources/start-program.

\section{On-Demand Technical Assistance} Tribes are eligible to receive up to 40 hours of technical assistance with clean energy projects. Apply online at www.energy.gov/ indianenergy/technical-assistance under Popular Topics.

\section{WINNING THE FUTURE}

Fuel from Waste Helps Power Two

\section{Tribes}

Challenge: Two Tribes-the Eastern Band of Cherokee Indians (EBCl) and the Mississippi Band of Choctaw Indians (MBCl)-had plenty of used vegetable oil and grease on hand and a desire to convert the waste to biofuel to reduce the environmental impact of their energy use. In considering biodiesel, they also wanted to ensure that vehicles required no modifications to run on this form of clean fuel.

Solution: United South and Eastern Tribes, Inc. (USET), a nonprofit intertribal organization that represents its member Tribes at the regional and national level, conducted a demonstration project on biodiesel production with these two Tribes in the hope that other Tribes could replicate the results on their own lands.

"The idea was to start small and slowly," said Lindy Colombini, who coordinated the project for USET. "Drivers and mechanics are understandably nervous about using an untested fuel in their trucks, and the risks and complexities of setting up a commercial operation were daunting."

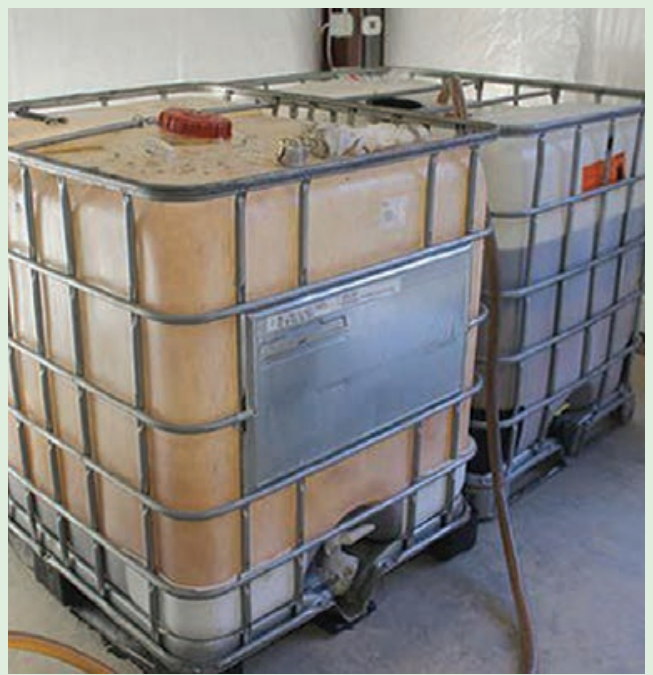

Waste vegetable oil and grease are used by the $E B C l$ to make biodiesel. Photo from EBCl, NREL 26449

Both Tribes are using the biodiesel in their own vehicles to test both the fuel and the production process. The $\mathrm{EBCl}$ project can produce up to 250 gallons in a 24-hour period from donated waste vegetable oil and grease. The Tribe's Natural Resources Department uses most of the fuel, and the Cherokee Boys and Girls Club has taken on the job of making biodiesel.
"The Boys and Girls Club members enjoy the process and learn about producing cleaner fuels," Colombini said. "It's become a community project, and so far the vehicles are running fine."

$\mathrm{MBCl}$ also started small, although as demand for biodiesel goes up and efficiency improves as operators become more familiar with the system, the production rate is expected to rise. The Pearl River Resort, a casino owned by the Tribe, donates its waste vegetable oil. The resort's maintenance crews use the biodiesel first, and the Tribe's Transportation Department uses any excess.

Both Tribes experienced similar challenges at the beginning of their projects, including deciding on a location, getting tribal members to trust using fuel from a noncommercial source, and choosing the right type of biodiesel processor. Read their lessons learned online at www.energy.gov/indianenergy/ listings/newsletter-features.

The projects were funded in part by U.S. Environmental Protection Agency grants. DOE has provided technical assistance to both Tribes in the past to help determine the feasibility of clean energy projects that could lead to increased economic development. 


\section{LEADING THE CHARGE CHRISTINE KLEIN}

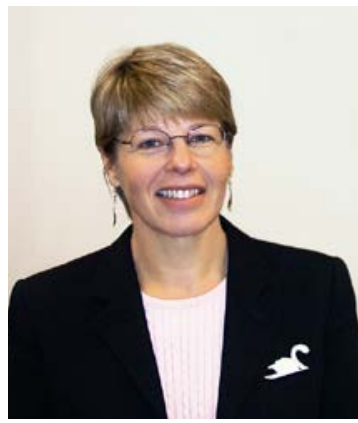

Christine Klein, Vice President/Chief Operating Officer of the Calista Corporation
Change doesn't happen on its own. It's led by dedicated and passionate people who are committed to empowering Indian Country to energize future generations. Leading the Charge is a regular feature spotlighting the movers and shakers in energy development on tribal lands.

Name: Christine Klein, Ja'adtlaa'wul

Tribe: Haida - Gawaa Gitans Gitanee

Title/Role: Vice President/Chief Operating Officer of the Calista Corporation

Christine Klein, an adopted Haida, grew up near the rural Village of Loring outside Ketchikan, Alaska. She was given her Haida name, Jaa'dtla'awul, as a small child by the Gawaa Gitans Gitanee Eagle Clan. Like many communities the Calista Corporation represents, Klein's home region previously suffered from staggering fuel costs and lack of jobs, and many people left. Cheaper hydropower helped some communities in the region survive and remain sustainable. Because energy often is at the heart of the crisis facing rural Native Alaskans, Klein has led efforts on behalf of Calista to advance projects that will lower demand for diesel fuel and reduce costs of living.

What energy challenges is your region currently facing? The Calista Corporation is one of the original 12 Alaska Native regional corporations established by the Alaska Native Claims Settlement Act in 1971. The region it serves spans 59,000 square miles in western Alaska and is home to 56 Tribes. The Native villages in this rural region are only accessible by plane or barge, and residents, like their predecessors, rely primarily on subsistence. There is no grid system or infrastructure to improve access to power. Nearly every village has its own diesel generator for electricity, and fuel is delivered once a year by barge.

Fuel costs are sky high-more than $\$ 7$ a gallon in the largest community and up to $\$ 11$ a gallon in the more remote areas. Unemployment and poverty rates in the region are among the highest in the country. Many Native communities are facing extinction as people move for jobs.

What motivates you to help address these challenges? I know what these Calista communities face. I lived it. I have a passion for our rural villages and want to do everything I can to help them. A lot of times, the wealth that comes from our rural resources tends to benefit urban areas most, but we also have a responsibility to our rural areas so they too can reap the benefits and survive.

What clean energy projects are you currently working on? Because Calista's communities' only access to fuel is by river barge, an oil spill will be disastrous to the fish people rely on for food. Our team is coordinating with all the villages to seek alternative energy solutions.

The corporation, along with many partners, supported a coastal wind turbine effort linking several villages and is leading a Chikuminuk Lake hydropower feasibility assessment. Calista is also supporting a region-wide grid feasibility plan.

What are your thoughts on the future of Native Alaska energy development? All our rural areas are at risk if we don't address the energy crisis. Doing nothing while these villages disappear would be unspeakable. If we don't get on top of this, your village might go away, like mine did. That's not something you want to tell people. But I can say that because I've seen it in my own lifetime. It all comes down to affordable energy. We've got to get basic transportation and energy infrastructure in place to survive. I think if we worked together, we would be a force to be reckoned with and will get things done.
ON THE

HORIZON

SEPT. 18-20

Community- and Facility-Scale Renewable Energy Project Development and Finance Workshop

Denver, Colorado

SEPT. 25

Tribal Renewable Energy Series Webinar: Tribal and Utility Partnership Opportunities

Sponsored by DOE and WAPA

0CT. 13-18

National Congress of American Indians Annual Convention \& Marketplace

Tulsa, Oklahoma

OCT. 21-23

Alaska Native Village Energy Development Workshop Fairbanks, Alaska

\section{CT. 24-26}

Alaska Federation of Natives Convention Fairbanks, Alaska

\section{OCT. 30}

Tribal Renewable Energy Series Webinar: Renewable Energy Project Case Studies: Tribal and Developer Perspectives Sponsored by DOE and WAPA

\section{FEATURED IN PAST ISSUES}

To read about tribal energy champions and tribal energy projects covered in previous issues of Indian Energy Beat, please visit www.energy.gov/indianenergy/listings/ newsletter-features.

\section{SUBMISSION IDEAS?}

Indian Energy Beat is a publication of the DOE Office of Indian Energy that highlights opportunities and actions to accelerate energy development in Indian Country. If you have suggestions for feature stories, interviews, or news relevant to Indian energy, please submit your ideas to indianenergy@hq.doe.gov.

\section{LEARN MORE}

For more information on the DOE Office of Indian Energy's efforts to accelerate next-generation energy development in Indian Country and build a 21st century tribal energy economy, visit: www.energy.gov/indianenergy or email: indianenergy@hq.doe.gov
U.S. DEPARTMENT OF

ENERGY

Office of Indian Energy energy.gov/indianenergy

indianenergy@hq.doe.gov 